Revista Brasileira de Farmacognosia Brazilian Journal of Pharmacognosy 21(3): 518-524, May./Jun. 2011

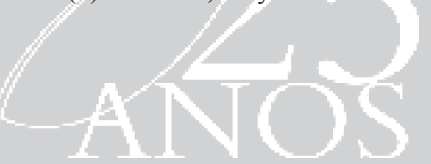

Article

Received 27 Aug 2009

Accepted 6 Sep 2010

Available online 6 May 2011

Keywords:

Echinodorus macrophyllus

fluid-extract

drying effect

conservation processes

pharmacochemical composition

ISSN 0102-695X

doi: 10.1590/S0102-695X2011005000075

\section{Drying of Echinodorus macrophyllus and auto- claving and lyophilization of the fluid-extract: effects on the pharmacochemical composition}

\author{
Ronam V. Flor, ${ }^{1}$ Maria Augusta A. Campos, ${ }^{1}$ Ana Gabriela $R$. \\ Solano, ${ }^{1}$ Lieselotte Jokl, ${ }^{2}$ Ana Maria Dantas-Barros ${ }^{*}, 1$
}

\author{
${ }^{1}$ Departamento de Produtos Farmacêuticos, Faculdade de Farmácia, Universidade \\ Federal de Minas Gerais, Brazil, \\ ${ }^{2}$ Departamento de Alimentos, Faculdade de Farmácia, Universidade Federal de \\ Minas Gerais, Brazil.
}

\begin{abstract}
Some pharmaceutical industries of phytomedicines are using conservation procedures (drying, autoclaving), in an attempt to avoid medicinal plants degradation, and of their fluid-extracts. Or, by adopting techniques adequate to foods, which not always are appropriate. On this sense, there is less research with Brazilian plants, causing some difficulties for their use as raw material by the domestic industry. Thus, the effects of drying at various temperatures or irradiation with microwaves, as well as autoclaving or lyophilization of the fluid-extract of samples collected in natura of Echinodorus macrophyllus (Kunth) Micheli, Alismataceae, on the pharmacochemical composition were analyzed. At the research for chemical groups, the preponderating presence of flavones and coumarin derivatives was observed. The chromatographic profiles of the flavonic extracts were analyzed by TLC and HPLC and the levels of total flavonoids were determined. According to the results obtained, qualitative and quantitative changes were caused by the various processes employed.
\end{abstract}

\section{Introduction}

Medicinal plants available in the national market have patterns of questionable quality. Some explanations for this situation are the scarcity of training from the suppliers, inappropriate drying processes, bad conservation and storage. The problem becomes more serious when this raw material is the basis for industries and drugstores which produce or manipulate phytotherapeutics, where several quality parameters are not followed (WHO, 2003).

In the industry, some manufacturers have used conservation processes, such as pasteurization and autoclaving, in an attempt to avoid the degradation. Or, they adopt techniques applied to foods which not always are appropriate to be used on medicinal plants, such as the irradiation by microwaves. Microwaves are suggested to dry medicinal plants, and constitute a form of electromagnetic radiation which varies in frequency, wavelength and energy content. When they interact with a material such as water, they produce heat. During the drying process, the real heating of the material is influenced by microwave frequency and its spectral distribution. The material's position in the cavity, moisture channel, its chemical composition and physical structure also influence the form of the material. Thus, applying microwave irradiation may be a less drastic method to minimize the microbial pollution and, at the same time, produce a careful drying of drugs in natura without substantially influencing compounds with therapeutic activity (Brantner \& Lücke, 1995).

Paris \& Moyse (1965-71) observed that higher temperatures dry vegetal material faster, inhibiting rapidly the action of enzymes or the microbial activity, and these factors may produce changes in the profile of the species chemical components. On the other hand, temperatures over $60{ }^{\circ} \mathrm{C}$ may change the cells metabolic content. Nevertheless, lyophilization (Paris \& Moyse, 1976) is a method known as mild which reduces to the minimum the degradation of the components, being employed in the pharmaceutical industry, inclusively in products containing enzymes, hormones, serum or plasma.

The scarcity of research regarding Brazilian native plants poses difficulties for their utilization as a raw material by the industry. In this context, falls within Echinodorus macrophyllus (Kunth) Micheli from the family Alismataceae, vulgarly known as "chapéu-decouro", "chá-mineiro", "erva-de-pântano", “erva-debugre", "congonha-do-campo" and "erva-do-brejo". The species E. macrophyllus is found in Brazil, particularly 
in the states of Minas Gerais and São Paulo, mainly in flooded areas (Ferrari, 1961; Correa, 1974; Cronquist, 1981; Rego, 1988). Its leaves are popularly used in the treatment of rheumatism, syphilis and as diuretic (Coimbra, 1994). The toxicity in vitro and in vivo of the aqueous extract of E. macrophyllus leaves was analyzed by Lopes et al. (2000), in experiments with rats, with no genotoxic effect. Although E. macrophyllus is listed in the Brazilian Pharmacopoeia (both in 1926 and in 1959), it is important to promote the research to its further use as a phytotherapeutic drug, also due to its commercial importance.

In studies on the chemical composition of the species, the presence of polyphenols, flavonoids and diterpenes has been verified (Kobayashi et al., 2000; Pimenta et al., 2000; Shigemori et al., 2002).

In an extensive research carried out at the Pharmacognosy Laboratory of the College of Pharmacy (UFMG) by Leite (1995), morpho-anatomical knowledge has been deepened and the most appropriate chemical marker has been identified for this species - flavonoids, aiming the quality control and the pharmacognostic analysis. At the current stage, the purpose was to evaluate several methods of drying the species and verifying possible effects of these processes on its pharmacochemical composition as well as the fluid-extracts prepared according to the Brazilian Pharmacopoeia (1926) and submitted to autoclaving and lyophilization.

\section{Materials and Methods}

\section{Plant material}

Leaves of Echinodorus macrophyllus (Kunth) Micheli, Alismataceae, were collected in the Natural History Museum and Botanical Gardens of UFMG, in Belo Horizonte-MG, Brazil (location: $1^{\circ} 27^{\prime} 21^{\prime \prime}$ S latitude and $48^{\circ} 30^{\prime} 14^{\prime \prime} \mathrm{W}$ longitude, at $920 \mathrm{~m}$ of altitude). A dried herbarium specimen for reference is held at the herbarium of the Biological Sciences Institute, UFMG, by the number BHCB 28.557. They were collected in November, a period in which the highest flavonoid contents are found in the plant, according to Leite (1995). Leaves measured from 20 to $35 \mathrm{~cm}$ of width, and 20 to 40 $\mathrm{cm}$ of length of limbos and petioles, to $70 \mathrm{~cm}$ of length. Just after collection, leaves were separated in petioles and limbos to make it easier to clean, washed under current water, followed by distilled water. Then, parts of the leaves were gathered again, mixed and weighed. Part of this material was cut in fragments and ground in a knife mill, which was made easier by the high moisture content - $83.2 \mathrm{~g} / 100 \mathrm{~g}$ (Leite, 1995), thus, the sample Plant in natura was immediately employed in the analyses. The other part was submitted to several drying processes, and the fluid-extracts were prepared by percolation, then the products were employed in the analyses.

\section{Drying}

For each drying process were used $500 \mathrm{~g}$ of the vegetal material was prepared in the same way as the sample Plant in natura. Then it was spread on a Kraft paper and submitted to drying at the following temperatures: i) room temperature, controlled daily, with the material placed at a ventilated place, protected from the light incidence and at the end, was identified by the general average; ii. 35,50 and $75^{\circ} \mathrm{C}$; the material was placed in an incubator with forced air circulation, at the respective temperatures, until they reached the preestablished characteristics; iii) microwaves irradiation was performed at the Laboratory of Food Technology, at the Pharmacy College, UFMG. The fragmented limbos from a leaf and the respective petiole cut in pieces of $1 \mathrm{~cm}$ were spread in one layer, in the middle of the microwave chamber. A medium-low and a medium energy range were used for 8 min continuously.

The end of the drying process was determined by the friability (fragile aspect) presented by leaves/petioles and no color change. All dried material was pulverized in a knife mill to fine powder (40 mesh). These samples were transferred to glass flasks with lids; identified as Plant dried at 'mean' ${ }^{\circ} \mathrm{C}$, Plant dried at $35^{\circ} \mathrm{C}$, Plant dried at $50^{\circ} \mathrm{C}$, Plant dried at $75^{\circ} \mathrm{C}$ and Plant irradiated by microwaves; stored at $18^{\circ} \mathrm{C}$ and protected from light.

\section{Percolation}

Part of the vegetable material which was collected and washed was employed to prepare the fluid-extract according to the Brazilian Pharmacopoeia (1926). It is important to highlight that the Brazilian Pharmacopoeia (1959) mentions this species, but not this process. Thus, $265 \mathrm{~g}$ of the Plant in natura were covered with a mixture of distilled water:ethanol (3:1) and remained in the covered recipient for $6 \mathrm{~h}$. After this period it was processed according to the pharmacopoeia and at the end extraction liquid was added to complete the final volume of $265 \mathrm{~mL}$. The fluid-extract obtained was divided in three parts. The first one $(65 \mathrm{~mL})$ was kept as sample Original fluid-extract, beeing transferred to a flask with lid and frozen. The second one $(100 \mathrm{~mL})$ was kept in an appropriate recipient and autoclaved, under humid heat of $120{ }^{\circ} \mathrm{C}$ for $20 \mathrm{~min}$. It was transferred to a flask with a lid, identified as Autoclaved fluid-extract and maintained frozen. And the last one $(100 \mathrm{~mL})$ was lyophilized, transferred to a flask with lid, identified as Lyophilized fluid-extract, and preserved at $18{ }^{\circ} \mathrm{C}$ and protected from light. 
Pharmacochemical study

\section{General triage of chemical groups}

It was performed in the respective sample extracts, using classical triage methods of chemical groups (Matos, 1988; Costa, 1996).

TLC chromatographic profiles of flavonic extracts:

Samples ( $2 \mathrm{~g}$ ) were used, and extracted with 10 $\mathrm{mL}$ of dichloromethane for $15 \mathrm{~min}$ under agitation. The extract obtained was filtered and concentrated at room temperature, being identified as nonpolar extract. The residue was extracted with $10 \mathrm{~mL}$ of methanol, for 10 min under agitation, filtered, concentrated and identified as polar extract (Paris \& Moyse, 1971; Wagner et al., 1984).

Fluid-extracts $(4 \mathrm{~mL})$ were extracted with 10 $\mathrm{mL}$ dichloromethane under agitation for $10 \mathrm{~min}$. After separating the phases, the organic was transferred to a capsule and concentrated at room temperature - nonpolar extract. The aqueous phase was transferred to a porcelain capsule, dried at room temperature until reaching a viscous consistency; then dissolved in methanol, and identified as polar extract.

For the chromatography, ethyl acetate:formic acid:water (80:10:10) was applied to the plate and employed as mobile phase; and as developers a UV lamp $366 \mathrm{~nm}$ followed by the mixture of boric acid:oxalic acid $(1: 1)$.

HPLC chromatographic profiles of flavonic extracts

Waters Maxima 820 data system with HPLC was employed with $225 \mathrm{~nm}$ detection. The analysis was performed in reverse phase, employing Novapack C18 column, 3.9 x $150 \mathrm{~mm}$, particles with $4 \mu \mathrm{m}$ of diameter, and using isocratic elution with water: methanol (70:30), $40{ }^{\circ} \mathrm{C}$, flow speed of $0.7 \mathrm{~mL} / \mathrm{min}$.

\section{Flavonoid contents}

Flavonoids were dosed according to Schmidt \& Ortega (1993), modified by Leite $(1995,2008)$. Thus, 8 $\mathrm{g}$ of the sample (in triplicate) were extracted in a Sohxlet extractor, employing $500 \mathrm{~mL}$ of diluted methanol (40 $\mathrm{mL} / 100 \mathrm{~mL})$. The extract was filtered while still hot through filter paper; after cooling the volume was completed to $500 \mathrm{~mL}$. A solution $(1 \mathrm{~mL})$ of aluminum trichloride $\left(0.5 \mathrm{~g} \mathrm{AlCl}_{3} / 30 \mathrm{~mL}\right.$ diluted methanol) was added to $5 \mathrm{~mL}$ of extract and then was completed with diluted methanol to $25 \mathrm{~mL}$. After agitating for $5 \mathrm{~min}$, followed by a $30 \mathrm{~min}$ rest, the absorbance reading is performed at $342 \mathrm{~nm}$, using as blank, only the mixture of $\mathrm{AlCl}_{3}$ and diluted methanol solutions. The result was expressed in percentage of flavonoids regarding the quercetin content.

Quercetin was chosen as standard/reference, because it reacts with $\mathrm{AlCl}_{3}$, presents maximum absorptions in the ultraviolet similar to those obtained for the flavonic extract when reacting with this salt (Leite, 1995). Thus, the standard quercetin solution was prepared in diluted methanol $(50 \mathrm{mg} / 100 \mathrm{~mL})$; aliquots $(\mathrm{mL})$ of $0.25 ; 0.50,1.0$ and 1.5 were used for the standard curve and dosage was followed as described for the samples:

Flavonoid content was calculated by the following equations:

$\mathrm{A}_{\text {corrected }}=\mathrm{A}_{\text {sample }}-\mathrm{A}_{\text {blank }}$ in which $\mathrm{A}=$ absorbance (1) $\%$ flavonoids $=[$ concentration $(\mathrm{mg} / \mathrm{mL}) /$ initial concentration $(\mathrm{mg} / \mathrm{mL})] \times 100$

Mean flavonoid contents determined for different samples were analyzed statistically by means of analysis of variance (ANOVA), with a significance level of 0.05 , and the means were compared by the Tukey test $(p \leq 0.05)$, according to the Microsoft Office Excel ${ }^{\circledR} 2003$ program.

\section{Results}

Drying

Due to the high moisture content of the plant, the drying time was reduced as the temperature rose: room temperature (mean $\left.25{ }^{\circ} \mathrm{C}\right) 96 \mathrm{~h} ; 35^{\circ} \mathrm{C}, 84 \mathrm{~h} ; 50{ }^{\circ} \mathrm{C}, 48 \mathrm{~h}$ and $75^{\circ} \mathrm{C}, 24 \mathrm{~h}$. The interference of high moisture levels has also been verified by Costa et al. (1999) for ironweed (Vernonia polyanthes Less.). But, different temperatures used in the present study have not affected the good aspect and the original color of the species, corroborating with what was verified by Rocha et al. (2000), when working with five drying temperatures for citronella grass (Cymbopogon winterianus Jowitt), although changes have been seen when drying at $75^{\circ} \mathrm{C}$. Corrêa et al. (2004) have already obtained a similar result by submitting leaves of ironweed to different drying methods. Natural colors of this species have been maintained: dark green, predominantly at the adaxial face and light green at the abaxial face.

The process of microwaves irradiation was also influenced by the high moisture level of the plant and its duration had to be increased in order to avoid very high energy levels, which may cause damage to the samples. The sample resulting from this process had a satisfying appearance, although its color was a little darker. Karting et al. (1994) have also obtained several samples of leaves, flowers, herbs and roots dried by microwaves irradiation 
with a significantly better appearance regarding color when compared to samples dried outdoors. Afterwards (Karting et al., 1995) found lower residual moisture content in almost all samples dried by microwaves when compared to those dried at room temperature. Therefore, few works have been done with national medicinal plants.

\section{Percolation}

The Original fluid-extract prepared from the Plant in natura had a good appearance and a characteristic odor. The fraction Autoclaved fluid-extract has not suffered any perceptible changes in its appearance and odor, when compared to the Original fluid-extract. In turn, lyophilization is an alternative conservation process and less employed. However, Bruneli-Geray \& Debelmas (1969) have already seen that organoleptic characteristics of the vegetables are better preserved by lyophilization. Thus, the Lyophilized fluid-extract resulted in a homogeneous fine loose powder with a little lighter color than that of the original fluid-extract. Powder reconstitution with $1 \mathrm{~mL}$ of distilled water, corresponding to $1 \mathrm{~mL}$ of Original fluid-extract is immediate and complete, restoring physical characteristics from before the lyophilization.

\section{Pharmacochemical study}

\section{General triage of chemical groups}

Saponins and anthracenes were not identified in the triage. Tertiary alkaloid traces were seen in all samples, except in the Plant dried at $50{ }^{\circ} \mathrm{C}$. No tannins were detected, but the remarkable presence of polyphenols, reinforcing the presence of phenolic hydroxyls, such as the flavonoids (Costa, 1996). With reactions to detect flavonic types, the significant presence of flavones, flavonols and/or flavanones was detected. The presence of coumarins and derivatives was also verified.

\section{Comparative TLC of flavonic extracts}

Chromatographic profile of the Plant in natura extract served as baseline/control (fluorescent yellow/ greenish stains with $\mathrm{R}_{\mathrm{f}} 0.11 ; 0.25 ; 0.62$; purple with $\mathrm{R}_{\mathrm{f}}$ 0.57 and blue with $R_{f} 0.72$ and 0.82 ) and in comparison it was verified that: a. yellow-greenish stains appeared in all samples, corresponding to flavonoids; b. blue stains appeared only in samples of dried plants and those irradiated by microwaves, corresponding to possible coumarinic derivatives; c. one new strong fluorescent yellow stain with $\mathrm{R}_{\mathrm{f}} 0.50$, present in all samples, except in the Plant in natura; d. one new fluorescent yellow stain with $\mathrm{R}_{\mathrm{f}} 0.40$, absent in Fluid-extracts.
Therefore, regarding the Plant in natura and regardless the drying process, a loss of substance with $R_{f}$ 0.57 (fluorescent purple), and the appearance of two new ones $\left(\mathrm{R}_{\mathrm{f}} 0.50\right.$ and 0.40$)$ were observed. When preparing the Fluid-extracts, in addition to these changes, there was also a loss of one more compound with $\mathrm{R}_{\mathrm{f}} 0.72$.

According to Castro et al. (2000), the high moisture content in the vegetal material favors reactions of oxidation, reduction, molecular rearrangement, hydrolysis, and adding or withdrawing radicals, resulting in changes in the active principles. The appearance of fluorescent yellow stains, absent in extracts from Plant in natura, may be explained by oxidative degradations which occurred in the extracts' components, during drying and microwaves irradiation processes, and possibly, favored by the high temperatures used.

During the research, it was tried to avoid heating the samples, more than it was proposed by the techniques. However, the preparation of the Fluidextracts is long, particularly in the step of concentration of the most diluted fraction, when forced ventilation was employed. This long air exposure (about $60 \mathrm{~h}$ ) may have incised the degradation level of the Original fluidextract components. Furthermore, it was found that when autoclaving $\left(120^{\circ} \mathrm{C}\right)$ this Fluid-extract it did not cause more changes than those that happened during its preparation.

The yellow fluorescent compound, which appears in the TLC array of the Lyophilized fluid-extract must be the resulting degradation product during the preparation of the Original fluid-extract. Paris et al. (1967) have already verified that lyophilizing petals of Rosa gallica L. caused considerable losses of essential oils and tannins, when compared to samples dried with conventional methods. The same was also found for Mentha piperita Huds. (L.) by Hérisset \& Besson (1967). Thus, with the results obtained with TLC, no drying process or concentration would be indicated, due to the changes in the pharmacological compounds.

\section{Comparative HPLC of flavonic extracts}

With chromatographic profiles obtained by HPLC, it was seen that the first peaks, with retention times of up to $3.5 \mathrm{~min}$, are similar and, therefore, little elucidating.

In the chromatogram of the plant in natura, the following peaks with retention time (min) were highlighted $=4.63 ; 5.97 ; 7.13 ; 10.86 ; 12.32$ and 15.71 . In those of the Dried plants, the following peaks with retention time were highlighted, with changes occurring when compared with the original material: a: $25^{\circ} \mathrm{C}(\min )=4.58 ; 5.94 ; 7.14 ; 10.89 ; 13.68$ and a new but less intense one at 25.10; and peak loss at 15.71 . b. $35^{\circ} \mathrm{C}(\min )=4.76 ; 6.47 ; 12.51$ and two new ones at 
19.15 and 23.98 ; and peak loss at $7.13 ; 10.86 ; 15.71$. c. $50{ }^{\circ} \mathrm{C}(\min )=4.38 ; 6.28 ; 11.74$ and 16.96 more intensified; and peak loss at 12.32 .

d. $75{ }^{\circ} \mathrm{C}(\min )=4.66 ; 5.93 ; 10.54$ and three other less intense and small peaks, located between 12 and 20; and peak loss at $7.41 ; 12.32 ; 15.71$.

e. Irradiated with microwaves $(\mathrm{min})=4.70 ; 6.15 ; 10.64$ $16.06 ; 19.18$ - the last one is new.

In the chromatograms of Fluid-extracts, peaks with retention time were highlighted, verifying changes when compared to that of the Plant in natura:

a. Original $(\mathrm{min})=4.32 ; 4.94 ; 6.03 ; 6.50 ; 10.62 ; 16.78$ and two new at 19.87 and 26.56 ;

b. Autoclaved $(\min )=4.45 ; 5.50 ; 15.71$ and two new at 18.22 and 23.87;

c. Lyophilized $(\min )=4.41$ and a new one at 24.86 .

Chromatographic profiles of HPLC confirmed changes verified by TLC, that is, of loss or gain of substances, being more or less severe. But, the drying process at the incubator at $50^{\circ} \mathrm{C}$ is the one which less causes the appearance of new compounds, probably degradation ones.

\section{Flavonoid contents}

After verifying through TLC and HPLC that qualitative changes have been caused by several processes, the next aim was to verify if they reflected on the total flavonoid contents in the samples. The average flavonoid contents are shown in Table 1.

Table 1. Mean flavonoid contents in the samples analyzed.

\begin{tabular}{cc}
\hline Samples & $\begin{array}{c}\text { Mean flavonoid content } \pm \mathrm{SD}^{1} \\
(\mathrm{~g} / 100 \mathrm{~g})\end{array}$ \\
\hline Plant in natura & $2.90 \pm 0.10 \mathrm{fg}$ \\
Plant dried at $50^{\circ} \mathrm{C}$ & $2.60 \pm 0.01 \mathrm{~g}$ \\
Plant dried at $75^{\circ} \mathrm{C}$ & $3.30 \pm 0.31 \mathrm{efg}$ \\
Plant dried at $25^{\circ} \mathrm{C}$ & $3.60 \pm 0.20 \mathrm{eg}$ \\
Plant dried at $35{ }^{\circ} \mathrm{C}$ & $4.80 \pm 0.01 \mathrm{~d}$ \\
Plant irradiated by & $3.30 \pm 0.31 \mathrm{efg}$ \\
microwaves & \\
Original fluid-extract & $8.98 \pm 0.01 \mathrm{c}$ \\
Autoclaved fluid-extract & $11.63 \pm 0.02 \mathrm{a}$ \\
Lyophilized fluid-extract & $9.82 \pm 0.01 \mathrm{~b}$ \\
\hline
\end{tabular}

${ }^{1}$ Means of triplicates \pm SD. Means followed by the same letter in column have not presented significant differences among each other, with $5 \%$ of probability by Tukey's test $(\mathrm{msd}=0.47)$.

In the Plant in natura an average flavonoid content of $2.90 \%$ was determined. Among all treatments analysed, the lowest level was in the Plant dried at 50 ${ }^{\circ} \mathrm{C}$, which was not significantly different from control. No significant difference was observed among contents of Plants dried at $25{ }^{\circ} \mathrm{C}, 75^{\circ} \mathrm{C}$ and those Irradiated by microwaves, although their levels are about $17 \%$ higher.
Flavonoid content in the Plant dried at $35{ }^{\circ} \mathrm{C}$ was $41 \%$ higher than in the samples of the others drying treatments. When compared to the Plant in natura, flavonoid levels were higher in the Fluid-extracts, due to likely degrading products which may affect the pharmacological action of the species.

Changes in the extract composition already verified in TLC and HPLC may be related to these increases in contents due to the appearance of new compounds, which would absorb in the same flavonic wavelength, when they react with $\mathrm{AlCl}_{3}$ at the dosing. The high moisture content of the plant may have favored oxidations, reductions, molecular rearrangements, hydrolyses and withdrawing or adding radicals, resulting in changes of active principles, as it was stated by Martins (1994).

Generally and based on results obtained in the current research, it was possible to state that the best option would be to use the Plant in natura. However, taking into account the different drying processes, the one at $50{ }^{\circ} \mathrm{C}$ would be the most appropriate, confirming the results reported in the literature for other species. Thus, Radünz et al. (2003) evaluating how several drying temperatures interfere in coumarin content of Mikania glomerata leaves, observed that samples dried at $50{ }^{\circ} \mathrm{C}$ presented a minor change regarding the plant in natura. Leaves of Maytenus ilicifolia ("espinheira-santa"), grown under the sun, were dried by Negri (2007) in an incubator at temperatures of $40,50,60,70$ and $80{ }^{\circ} \mathrm{C}$. When dosing polyphenols, it was concluded that drying temperatures influence total polyphenol and tannin contents, recommending lower temperatures for this process. Diniz et al. (2007) assessed the drying effect on the amount of flavonoids and hypericin in vegetative parts of Hypericum perforatum L. (hypericum). When compared to the fresh material, the process reduced significantly free rutin and quercetin levels, and changed the flavonoid profile of the hydrolyzed extract. The most dramatic change occurred when drying at $25^{\circ} \mathrm{C}$; and at $70{ }^{\circ} \mathrm{C}$, with the reduction of levels of most compounds analyzed. However, there was no change in the one at 50 ${ }^{\circ} \mathrm{C}$.

Phytotherapeutic preparations of $E$. macrophyllus are usually obtained with the use of heating. With the present results, a question is raised whether the change caused by the heat would interfere in the plant's pharmacological activity. Thus, further studies are important to better understand the results obtained. Also, it is possible to state that the most important aspects to be considered when submitting a plant to any processing method is that it maintains appropriate levels of the active substance as well as the pharmacological effect. 


\section{Conclusions}

After triage, the presence of flavonoids and coumarinic derivatives were seen in all samples analyzed. Changes seen in TLC and HPLC profiles refer to at least two degradation compounds. Such results were confirmed by dosing total flavonoids in the samples. All processes used brought about remarkable changes in fluid-extracts. Preferably, a freshly collected in natura plant should be used, as the presence of degradation compounds may affect its use from the pharmacological point of view. When it is not possible to use the Plant in natura, the chosen method, among all those tried, should be drying at $50^{\circ} \mathrm{C}$.

\section{References}

Brantner A, Lücke W. 1995. Influence of physical parameters on the germ-reducing effect of microwave irradiation on medicinal plants. Pharmazie 50: 762-766.

Bruneli-Geray J, Debelmas AM 1969. Contribution a l'étude de 1'Arnica montana L. Plantes Méd Phythothér 3: 15-19.

Castro DM, Castellani DC, Martins, ER, Dias JE. 2000. Plantas medicinais. Viçosa: Editora Universidade Federal de Viçosa.

Coimbra R. 1994. Manual de fitoterapia. Belém: Editora CEJUP.

Correa PM 1974. Dicionário das plantas úteis do Brasil e das exóticas cultivadas. Rio de Janeiro: Ministério Agricultura.

Corrêa RM, Bertolucci SKV, Pinto JEBP, Reis ES, Alves TL 2004. Rendimento de óleo essencial e caracterização organoléptica de folhas de assa-peixe submetidas a diferentes métodos de secagem. Cienc Agrotec 28: 339344.

Costa AF 1996. Farmacognosia. Lisboa: Fundação Calouste Gulbenkian.

Costa CC, Casali VWD, Andrade NJ. 1999. Avaliação da droga Vernonia polyanthes L. - "assa-peixe" obtida a partir de dois métodos de secagem e em duas épocas de coleta. Rev Bras Pl Med 2: 7-11.

Cronquist A 1981. An integrated system of classification of flowering plants. New York: Columbia University.

Diniz ACB, Astarita LV, Santarém ER. 2007. Alteração dos metabólitos secundários em plantas de Hypericum perforatum L. (Hypericaceae) submetidas à secagem $\mathrm{e}$ ao congelamento. Acta Bot Bras 21: 442-450.

Farmacopéia dos Estados Unidos do Brasil 1959. 2a. ed. São Paulo: Indústria Gráfica Siqueira.

Ferrari JM 1961. Contribuição ao estudo das Monocotyledoneae medicinais indigenas da Zona Metalúrgica do Estado de Minas Gerais. Belo Horizonte, 126 p. Tese de Doutorado, Instituto de Ciências Biológicas, Universidade Federal de Minas Gerais.

Hérisset A, Besson Ph 1967. Attempt of "industrial lyophilization" of medicinal plants. V. Peppermint (Mentha piperita Huds L.). Ann Pharmac Fr 25: 673-677.

Karting Th, Lücke W, Lassing Ch 1994. The application of microwave energy in preparing medicinal plant drugs. 1. Pharmazie 49: 610-613.
Karting Th, Hörsten DV, Lassing Ch, Classen B 1995. The application of microwave energy in preparation of herbal drugs. 2. Pharmazie 50: 498-504.

Kobayashi J, Sekiguchi M, Shigemori H, Obsaki A 2000. Echinophyllins $\mathrm{A}$ and $\mathrm{B}$, novel nitrogen-containing clerodane diterpenoids from Echinodorus macrophyllus. Tetrahedron Lett 41: 2939-2943.

Leite JPV 1995. Contribuição para o estudo farmacognóstico do Echinodorus macrophyllus (Kunt) Mich. (Chapéude-couro). Belo Horizonte 86p. Monografia de Especialização em Farmácia, Faculdade de Farmácia, Universidade Federal de Minas Gerais.

Leite JPV 2008. Fitoterapia - bases científicas e tecnológicas. São Paulo: Atheneu.

Lopes CL, Albano F, Laranja GAT, Alves LM, Martins e Silva LF, De Souza GP, Araújo IM, Nogueira-Neto JF, Felzenszwalb I, Kovary K 2000. Toxicological evaluation by in vitro and in vivo assays of an aqueous extract prepared from Echinodorus macrophyllus leaves. Toxicol Lett 116: 189-198.

Martins ER 1994. Plantas medicinais. Viçosa: Editora Universidade Federal de Viçosa.

Matos FJA 1988. Introdução à fitoquímica experimental. Fortaleza: Editora Universidade Federal do Ceará.

Negri MLS 2007. Secagem das folhas de espinheira-santa - Maytenus ilicifolia Mart. Ex Reiss. sob diferentes temperaturas e influência nos teores de polifenóis, na atividade antioxidante e nos aspectos microbiológicos. Curitiba,79 p. Dissertação de Mestrado, Ciências Farmacêuticas, Universidade Federal do Paraná.

Paris RR, Moyse H 1965-1971. Matière medicale. Paris: Massom.

Paris RR, Besson Ph, Hérisset A 1967. Attempt of "industrial lyophilization" of medicinal plants. IV. Red rose (Rosa gallica L.). Ann Pharmac Fr 25: 453-457.

Paris RR, Moyse H 1976. Matière medicale. 2a. ed. Paris: Massom.

Pharmacopeia dos Estados Unidos do Brasil. 1926. São Paulo: Companhia Editora Nacional.

Pimenta DS, Figueiredo MR, Kaplan MAC 2000. Chemical studies on cultivation of Echinodorus grandiflorus Cham. \& Schl.) Mich. An Acad Bras Cien 72: 294.

Radünz LL, Melo EC, Berbert PA, Barbosa LCA, Santos RHS, Rocha RP 2003. Influência da temperatura do ar de secagem na quantidade do óleo essencial extraído de guaco (Mikania glomerata Sprengel) Rev Bras Armaz 28: 41-45.

Rego SCA 1988. Alimastaceae. Porto Alegre: 67 p. Tese de Mestrado, Ciências Farmacêuticas, Universidade Federal do Rio Grande do Sul.

Rocha SFR, Ming LC, Marques MOM. 2000. Influência de cinco temperaturas de secagem no rendimento e composição do óleo essencial de citronela (Cymbopogon winterianus Jowitt). Rev Bras Pl Med 3: 73-78.

Schmidt VPC, Ortega GG 1993. Passionsblumenkraut: Bestimmung des Gesamtflavonoidgehaltes von Passiflorae herba. Deut Apoth Z 47: 17-26.

Shigemori H, Shimamoto S, Sekiguchi M, Ohsaki A, Kobayashi J 2002. Echinodolides A and B, new cembranes diterpenoids with an eight-membered lactone ring from the leaves of Echinodorus macrophyllus. J Nat Prod 65: 
82-84.

Wagner H, Blast S, Zgainski EM. 1984. Plant drug analysis. Berlim: Springer-Verlag

World Health Organization 2003. WHO Guidelines on agricultural and collection practices (GACP) for medicinal plants. Geneva: World Health Organization.

\section{*Correspondence}

Ana Maria Dantas-Barros

Departamento de Produtos Farmacêuticos, Faculdade de Farmácia, Universidade Federal de Minas Gerais

Av. Antônio Carlos 6627, 31270-010 Belo Horizonte-MG, Brazil

dantasb@ufmg.br

Tel: +553134096946 